\title{
REVIEW
}

\section{Impaired Vitamin D Sensitivity}

\author{
L. MÁČOVÁ ${ }^{1}$, M. BIČÍKOVÁ ${ }^{1}$, R. HAMPL ${ }^{1}$ \\ ${ }^{1}$ Institute of Endocrinology, Prague, Czech Republic
}

Received July 2, 2018

Accepted August 20, 2018

\begin{abstract}
Summary
Resistance to vitamin $D$ has been known for decades as vitamin $\mathrm{D}$ resistant rickets, caused by mutations of the gene encoding for vitamin D receptor (VDR). Findings of extra-skeletal effects of vitamin $D$ and learning of the molecular mechanisms used by its biologically active metabolite calcitriol revealed other ways leading to its impaired sensitivity. Calcitriol takes advantage of both genomic and non-genomic mechanisms through its binding to vitamin $D$ receptor, located not only in the cell nuclei but also in a perinuclear space. On the genomic level the complex of calcitriol bound to VDR binds to the DNA responsive elements of the controlled gene in concert with another nuclear receptor, retinoid $\mathrm{X}$ receptor, and expression of the VDR itself is controlled by its own ligand. These elements were found not only in the promotor region, but are scattered over the gene DNA. The gene expression includes a number of nuclear transcription factors which interact with the responsive elements and with each other and learning how they operate would further contribute to revealing causes of the impaired vitamin $D$ sensitivity. Finally, the examples of major disorders are provided, associated with impairment of the vitamin $D$ function and its receptor.
\end{abstract}

\section{Key words}

Vitamin D • Resistance • Molecular mechanism

\section{Corresponding author}

R. Hampl, Institute of Endocrinology, Národní 8, 11694 Prague 1, Czech Republic. E-mail: rhampl@endo.cz

\section{Introduction}

As vitamin D we usually mean a group of secosteroids formed from nutritional ergosterol or body 7-dehydrocholesterol in skin by UV light. The biologically active molecule is 1,25-dihydroxy-vitamin $\mathrm{D}_{3},\left(1,25(\mathrm{OH})_{2}\right.$ cholecalciferol or calcitriol), formed from the precursors by two hydroxylations. Its major effect is maintaining calcium homeostasis in concert with peptide hormones parathormone and calcitonin, but recent research brought evidence that its spectrum of activities is much broader.

As in the case of other hormonal steroids, a resistance or impaired sensitivity to vitamin $\mathrm{D}$, either inherited or acquired, occurs. Vitamin D resistance is defined a state where organism is sufficiently supplied with vitamin $\mathrm{D}$, but it does not respond properly. Recognition of the causes of vitamin D resistance was enabled by revealing its mechanisms of action. In the following text we provide the brief history and milestones in understanding of vitamin $\mathrm{D}$ resistance and molecular mechanisms staying behind. Briefly we will touch the main targets of vitamin $\mathrm{D}$, including extra-bone ones and related pathologies.

\section{History of vitamin D resistance}

The vitamin D resistance has been long observed in patients with rickets not responding to vitamin D supplementation, often accompanied by alopecia. An intensive research started in late seventies and early eighties, after discovery of receptor mechanism of steroid hormone action. Liberman et al. (1980) was among the first who suggested vitamin D resistance as a result of changes at the receptor level. The same authors described unmeasurable uptake of $1,25(\mathrm{OH})_{2} \mathrm{D}_{3}$ into cell nuclei using tritium labeled hormone in bone tissue culture from patient with the syndrome of rickets, alopecia, 
hypocalcemia, and high circulating levels of 1,25-dihydroxyvitamin $\mathrm{D}_{3}\left(1,25(\mathrm{OH})_{2} \mathrm{D}_{3}\right)$ (Liberman et al. 1983). Hughes et al. (1991) brought evidence that the molecular basis of these disorders may be caused by genetic mutations in the gene encoding receptors for these hormones, by analyzing the vitamin $\mathrm{D}$ receptor protein, mRNA, and DNA from patients with hypocalcemic vitamin D-resistant rickets (Hughes et al. 1991).

Further attempts to classify the reasons for vitamin D resistance followed soon. In brief these were 1) failure in biosynthesis, and 2) non-functional vitamin D receptor, manifesting as two clinical disorders, vitamin D dependent rickets type I and type II, respectively. Type I is caused by the deficiency of 25-hydroxyvitamin D 1 $\alpha$-hydroxylase gene (CYP27B1), while type II consists in the defect of receptor for 1 $\alpha, 25$-dihydroxyvitamin D. Both are inherited in an autosomal recessive fashion (Hewison et al. 1994). The third cause of vitamin D resistance is closely connected with later detailed recognition of molecular events after binding of $1,25(\mathrm{OH})_{2} \mathrm{D}_{3}$ to the responsive elements in the promoter region of the regulated gene. It consists in an overexpression of so called non-vitamin D receptor (VDR)-related, vitamin D response elementbinding protein (VDRE-BP) and in the role of other proteins involved in the signaling cascade. It will be discussed below in the paragraph concerning molecular mechanism(s) of receptor mediated vitamin D action (Chen et al. 2000, Chen et al. 2003, Adams et al. 2004).

\section{Physiological effects of vitamin D and their mechanisms}

Biological effects of D-vitamin are well known. The major targets of biologically active form of vitamin $\mathrm{D}, 1,25(\mathrm{OH})_{2} \mathrm{D}_{3}$ are intestine, kidney and bones, where it, in concert with other calciotropic hormones, maintains calcium balance. In brief in intestine and kidney it stimulates resorption of calcium ions by promoting gene expression and function of transport proteins involved in calcium absorption and utilization, such as calbindin, TRPV6, osteocalcin, osteopontin, bone sialoprotein, TRPV6, PTH, PTHrp, enzymes involved in vitamin D biosynthesis and metabolism Cyp24a1 and as well as many others. In both organs it leads to an increase of circulating calcium. In bones vitamin $\mathrm{D}$ promotes bone resorption by increasing osteoblast number, influences formation of collagen in osteoblasts and bone mineralization. Besides maintaining calcium homeostasis vitamin D possesses many other functions which are apparent from non-skeletal diseases associated with its insufficiency. These include a broad spectrum of autoimmune diseases, bacterial and viral infections, cancer, cardiovascular diseases, and even neurodegenerative disorders (Grober et al. 2015).

For its regulatory effects in target cells vitamin $\mathrm{D}$ takes advantage of both genomic and non-genomic actions. Regulation of target gene expression, genomic effects are mediated by vitamin D receptor (VDR). VDR is a transcription factor belonging to steroid-retinoid family. Following its discovery in 1974, details of VDR structure and the gene which codes for it were completed (Haussler et al. 1998, Pike and Meyer 2010). As other receptors of steroid-retinoidthyroid family, VDR protein consists of three domains, a DNA binding domain with characteristic zinc fingers, a C-terminal ligand-binding domain with three dimensional binding pockets, both connected by so called hinge region, and the most variable transactivation domain mediating in concert with other transcription protein-factors triggering of the regulated gene expression.

\section{Genomic effects of vitamin D}

About $3 \%$ of the genes forming the human genome are regulated by vitamin $\mathrm{D}$ resp. its active form $1,25(\mathrm{OH})_{2} \mathrm{D}_{3}$ (Bouillon et al. 2006). VDR was detected in various tissues and cells, most of which have been identified as vitamin D targets. Tissue- and cell typespecific distribution of VDR throughout the body, together with a survey of experimental techniques used for this purpose have been reviewed by Wang et al. (2012).

According to simplified concept the binding of $1,25(\mathrm{OH})_{2} \mathrm{D}_{3}$-VDR complex to the responsible elements in the promoter region of the regulated gene (VDREs) initiates a formation of an assembly of nuclear transcription factors, the cross-talk of which functions as a bridge between the transactivation domain of the receptor and the gene initiation site, making it accessible to mRNA polymerase. Recent findings revealed that the mechanism is much more sophisticated and complex. A new insight on these mechanisms brought among others a technique known as chromatin immunoprecipitation (ChIP) analysis, based on determination whether a given protein binds to a specific DNA sequence (Vinckevicius and Chakravarti 2012). 
In the following we attempt to outline the main findings, the understanding of which may be helpful for explanation of vitamin D insensitivity.

1) Activated VDR (i.e. VDR with bound ligand), does not bind to VDRE alone, but in the heterodimeric complex with retinoic $\mathrm{X}$ receptor (VDR/RXR). Retinoid X receptors were initially identified as nuclear receptors binding the vitamin A derivative 9-cis retinoic acid, but their occurrence is much broader. They accompany many other nuclear receptors including VDR, with which they function as obligatory partners (Gilardi and Desvergne 2014, Christakos et al. 2016). Vitamin D response elements are composed of two hexametric nucleotide halfsites separated by three base pairs and thus bind activated VDR and RXR, respectively (Pike and Meyer 2010). VDR/RXR-heterodimer formation and its binding to DNA is critical for $1,25(\mathrm{OH})_{2} \mathrm{D}_{3}$ regulation of gene transcription. The structure of the liganded VDR/RXR complex was recently characterized using cryoelectron microscopy, X-ray scattering, and hydrogen deuterium exchange (Christakos et al. 2016). The combination of binding of VDR and RXR to responsive elements confers the gene regulation selectivity (Pike et al. 2016, Long et al. 2015).

2) There are not only one VDR/RXR regulated elements in the regulated gene. Besides regulatory elements in the promoter region, close to the initiation site of transcription, there are other VDR/RXR regulated elements scattered over the DNA, often located many kilobases upstream, downstream or within the transcription units of their respective gene's start site. Binding of VDR/RXR to these regulatory elements regulates - promotes or inhibits - the complex actions of nuclear proteins functioning as above mentioned enhancers or co-activators, mediating transactivation by making accessible the gene initiation site for mRNA polymerase. Such coregulatory proteins interact directly with VDR and some of them possess enzymatic activity including mRNA polymerase itself (Pike and Meyer 2010, Haussler et al. 2013, Tuoresmäki et al. 2014).

3) Vitamin D autoregulates its own receptor transcription. It has been known since eighties that $1,25(\mathrm{OH})_{2} \mathrm{D}_{3}$ upregulates the level of VDR gene expression, but the original studies did not find VDRE to $1,25(\mathrm{OH})_{2} \mathrm{D}_{3}$ at the promoter region of the VDR gene. Recent work using ChIP-sequencing analysis however revealed presence of VDR gene enhancers as well as additional sites of VDR-binding sites across the VDR gene (Lee et al. 2015, Pike et al. 2016). An over review of regulatory factors influencing VDR function was provided by Saccone et al. (2015). We should mention here also the effect of sex steroids on VDR expression (Herian et al. 2018). Besides heritable genetic predispositions mentioned here it depends on availability and supply of VDR ligand, given by environmental factors and, last but not least, on epigenetics. As the latter concerns, DNA methylation at various sites of the VDR gene, not only in the promoter region, histone modification and microRNA regulation elements within the VDR gene have been described (Saccone et al. 2015).

\section{Non-genomic actions of vitamin D}

Some effects of vitamin D in target cells are too rapid to be explained by stimulation of gene expression. The first attempts to prove VDR in the cell membrane has not been successful (Barsony et al. 1997), though its extranuclear or perinuclear localization in various tissues was well documented (Ordóñez-Morán and Muñoz 2009, Zanatta et al. 2011, Buitrago et al. 2013). Putative membrane receptor as a protein in calveolae of plasma membrane, which binds $1,25(\mathrm{OH})_{2} \mathrm{D}_{3}$ and triggers rapid responses was however later detected in many tissues and cell cultures as e.g. in chick, rat, mouse intestine; mouse lung and kidney; and human NB4 and rat leukemia cells.

Its existence was proven by various experimental techniques as immunodetection, confocal immunofluorescence microscopy or competitive binding assays, though its identity with nuclear VDR protein was not unambiguously confirmed (Huhtakangas et al. 2004). The "membrane VDR" is accompanied by another calveolae-located receptor protein named, due to its enzymatic activity, protein-disulfide isomerase family extranuclear VDR (Pdia3). With its bound cognate ligand initiates a number of direct or indirect actions consisting in activation of phospholipase A2 and protein kinase C, thus triggering signaling pathways via second messengers formation including calcium ions release (Doroudi et al. 2015). All the events occur in concert with the actions on nuclear level, as reviewed by Hii and Ferrante (2016).

\section{Vitamin D resistance}

Recently we published in this journal a review on steroid hormone resistance (Hampl and Vondra 2017). Vitamin D resistance is not an exception. For decades it is known in patients with rickets who did not respond to vitamin D supplementation. This phenomenon was later observed in other diseases taking advantage of vitamin D therapy. Having recognized the molecular mechanisms of 
vitamin D action, it was clear now that the cause need not lay only in the impaired function of the VDR or the key enzymes of vitamin D biosynthesis and metabolism, but also in disorders in quality and function of other factors involved in both transactivation process (in genomic mechanism) or signaling in non-genomic regulations. Inherited vitamin D resistance is thus caused by mutation of the respective genes, first of all the VDR/RXR gene and the genes encoding for 1 $\alpha$ - and 24-hydroxylase, respectively (CYP27B1 and Cyp24a1). Acquired vitamin $\mathrm{D}$ resistance may be developed by impairing any of above mentioned factors including VDR/RXR itself, as e.g. by infection, cancer or autoimmune process. The issue of acquired vitamin $\mathrm{D}$ resistance emerged in connection with attempts for treatment of human diseases such as osteoporosis, cancer, and secondary hyperparathyroidism. Novel drugs have been developed combining effects of $1,25 \mathrm{D}$ analogs and histone deacetylase inhibitors (Fischer et al. 2012).

\section{Inherited vitamin D resistance due to VDR/RXR mutations}

Since isolation and characterization of VDR and its gene, a number of authors reported mutations of the VDR gene. Most of them used cultured skin fibroblast from children with vitamin D resistant rickets (VDRR). The first papers appeared in late eighties by Hughes' group from Houston (Texas). Generally VDRR caused by VDR gene mutation is an autosomal recessive disorder and may affect any of three VDR domains as well as the gene for RXR. Single mutations have been found in DNA binding domain near the zinc fingers, characterized by normal $1,25(\mathrm{OH})_{2} \mathrm{D}_{3}$ binding, but with all other symptoms of VDRR (Hughes et al. 1988, Sone et al. 1989). Later the same group demonstrated simultaneous defects in two receptor domains, a missense mutation in the ligand binding domain and a nonsense mutation in the DNA binding domain, respectively (Hughes et al. 1991). Further experiments of the above group with skin fibroblast or blood lymphocytes provided a surprising result that tissue resistance need not be caused only by VDR mutations, but by its defective nuclear localization (Hewison et al. 1993).

Development of the first ELISA for VDR determination enabled to measure its concentration in various materials as skin fibroblast and peripheral blood lymphocytes in the range of tens of picograms (Sandgren and Deluca 1989). The method exerted a high specificity since it did not detect mutated VDR gene caused by a defect in a stop codone (Wiese et al. 1993).
Tens reports and casuistics on mutations in various domains of the VDR followed rapidly. Besides Hughes and Feldman groups (Houston, Texas and Stanford, California) the teams of DeLuca from Madison (Wisconsin), Haussler from Tuscon (Arizona) and Pike or Hewison (London, UK) should be mentioned at least. Here we will point to two findings demonstrating the various causes of impairment of VDR function not only due to its gene mutations. Concerning the role of VDR-RXR heterodimerization, the point mutation led to an impaired heterodimeric interaction with retinoid $\mathrm{X}$ receptor (Whitfield et al. 1996, Haussler et al. 1997). Of interest may be a finding of absence of one exon in patient's RNA, which was not due to a deletion in genomic DNA, but was caused by exon skipping during RNA processing, demonstrates that impairment of VDR function may be caused also by posttranscriptional events. The exhaustive list of all VDR mutations would be highly above the scope of this paper. Therefore we provide a few recent reviews summarizing the problematic of VDR mutations (Koren 2006, Malloy and Feldman 2011, Jolliffe et al. 2016).

Besides overt mutations of the VDR gene a considerable number of polymorphisms have been described, the carriers of which may be in risk for development of certain disorders linked with impaired calcium metabolism (Nicolaidou et al. 2007), especially renal diseases (Yang et al. 2015). The polymorphisms such Apal, Bsml, Tokl and Tql are registered under SNP database (see rs codes 7975232, 1541410, 222870 and 731236, respectively).

\section{Other causes of vitamin D resistance}

The most common cause of VD resistance besides VDR mutations is an impairment of the synthesis of biologically active form of vitamin D, 1,25-dihydroxycholecalciferol (calcitriol), known also as vitamin D resistant rickets type I due to deficiency in major enzymes involved, first of all of 25-hydroxyvitamin D 1 $\alpha$-hydroxylase gene (CYP27B1) expression. The action of this mitochondrial enzyme localized in kidney (but also in other cells) is a rate limiting step in bioactivation of vitamin D (Portale and Miller 2000). Numerous reports and reviews are available on this issue concerning the mutations of the above gene as e.g. Kato (1999), Kim et al. (2007), Miller (2017). The mutation of genes encoding for other enzymes of active vitamin D do exist as well, but are relatively rare (Miller 2017). 
Impaired production of calcitriol has a severe impact on increased synthesis and secretion of PTH in parathyroid major cells generating parathyroid hyperplasia, as occurs in chronic kidney disease. High circulating levels of parathyroid hormone (PTH) cause osteitis fibrosa, bone loss, and cardiovascular complications. Of interest here is an indirect mechanism of negative loop between calcitriol and PTH gene transcription and secretion via autocrine transforming growth factor alpha (TGF $\alpha$ )/epidermal growth factor receptor (EGFR) (Dusso et al. 2004).

A new insight into the mechanism of vitamin D resistance brought Chen et al. (2000). As mentioned above (see History of vitamin D resistance), vitamin D resistance may be caused also by overexpression of so called non-vitamin D receptor (VDR)-related, vitamin D response element-binding protein (VDRE-BP), which sequelches vitamin $\mathrm{D}$-directed transactivation. In this case, the expression of VDR is not altered. The latter protein shares homology with ubiquitous proteins called human heterogeneous nuclear ribonucleoprotein (hnRNP) A1 and hnRNPA2 (Adams et al. 2004). They are a family of conserved nuclear proteins that interact with nascent mRNA and as such regulate post-transcriptional events and thus affect expression of many genes (Bekenstein and Soreq 2013). Of interest is their association with neurodegenerative disorders, where they may function as a link between vitamin D insufficiency, known to occur in patients suffering from these diseases (Chen et al. 2003). Besides vitamin D response element-binding protein there exist intracellular proteins capable to bind directly 25-hydroxylated vitamin $\mathrm{D}$ metabolites. In contrast to VDRE-BP their interaction with vitamin D metabolites increases vitamin $\mathrm{D}$ receptor directed target gene expression (Adams et al. 2004).

Well known are anticancerous antiproliferative effects of vitamin D. Through its receptor, expressed in most malignant cells, calcitriol can inhibit a wide variety of genes involved in DNA replication, repair and cell cycling (Bouillon et al. 2006). Unfortunately, as clinical experience shows, after prolonged treatment the cancerous cells develop a resistance to vitamin D. A typical example is acquired resistance to vitamin $\mathrm{D}$ in colon cancer (Giardina et al. 2012). Revealing the molecular mechanisms staying behind thus possess a great therapeutical potential.

Finally, sensitivity to vitamin D decreases with aging. A typical example is development of intestinal resistance to calcitriol at higher age, which hampers intestinal calcium uptake and is characterized by decrease of VD receptor number (de Jongh et al. 2017).

\section{Pathologies associated with vitamin D resistance}

There are thousands reports and reviews on the clinical consequences of vitamin D deficiency, as e.g. Galesanu and Mocanu (2015). On the other hand, with exception of vitamin D resistant rickets, the data of vitamin $\mathrm{D}$ resistance in other diseases, many of which known to be associated with vitamin D deficiency, are relatively scarce. In contrast to overt VDR mutations, most of them are associated with polymorphisms in various parts of the VDR gene. The typical examples are shown below. We have listed only meta-analyses from the last five years and did not mention all diseases associated with vitamin D deficiency since it would by far exceed the frame of this review.

\section{Vitamin D resistant rickets}

The clinical impacts of vitamin D receptor impairment or defects in vitamin D biosynthesis, known as vitamin D resistant rickets type I and type II, have been discussed in previous paragraphs. More rare are cases caused by a defect in VDR signaling. This issue belongs to recent one and new findings may be expected soon.

\section{Immunopathologies}

Vitamin D is a necessary for proper function of the immune system and fight against infection. Cells of both innate and adaptive immunity are targets for vitamin D. While cells of the innate immunity possess vitamin $\mathrm{D}$ receptors regardless of their activation stage, cells of the lymphoid lineage express these receptors only at certain stages of their differentiation after activation (Manolagas et al. 1985, Trochoutsou et al. 2015).

Disorders associated with vitamin D deficiency represent a worldwide problem and include a broad range of diseases from most dangerous infections as tuberculosis to autoimmune diseases as are e.g. inflammatory bowel or Crohn disease (Lang and Aspinall 2017, Ardesia et al. 2015, White 2018). The list of these diseases would by far exceed the scope of this paper. On the other hand, disorders which may be ascribed to impairment of VDR mediated signaling are less frequent. The examples are immune-mediated diseases due to lack of VDR expression after long activation of 
T-helper cells (Cantorna and Waddell 2014).

Using gene screening for VDR a number of case studies were performed on association of VDR polymorphism with diabetes mellitus type 1 as a typical autoimmune disease. We may refer here at least to the meta-analysis from Turkish authors, who concluded that individual VDR polymorphisms do not seem to be associated with diabetes type 1 risk (Tizaoui et al. 2014).

\section{Neurodegenerative and neuropsychiatric diseases}

Population studies were performed of association of VDR gene polymorphisms with most severe neurodegenerative diseases as Alzheimer's dementia, multiple sclerosis and Parkinsonism. An open issue is the incidence of autism in subjects with vitamin $\mathrm{D}$ deficiency and the mechanism staining behind it (Máčová et al. 2017).

A study of Alzheimer patients $(n=108)$ compared frequency of the known VDR gene polymorphisms usually depicted as TaqI, ApaI, FokI and Bsm with the control group ( $\mathrm{n}=77)$. With exception of decreased occurrence of the allele ApaI in Alzheimer patients, no clear evidence for association of VDR gene polymorphism with the disease were brought (Laczmański et al. 2015). A similar data were obtained in an elder Turkish study focused on late onset of Alzheimer's disease (Gezen-Ak et al. 2012). Of interest may be the results of one of the earliest study (Sutherland et al. 1992) on VDR mRNA formation in cultured hippocampal CA1 cells from Alzheimer patients. The authors demonstrated down regulation of VDR mRNA, pointing to importance of VDR autoregulation mentioned in previous paragraphs.

Multiple sclerosis belongs to neurodegenerative diseases believed to be strongly influenced by vitamin $\mathrm{D}$ supplementation, depending on proper VDR function (Penesová et al. 2018). A search of key words VDR and multiple sclerosis provided 50 references and 5 reviews. Let us mention here at least the reviews of the Dutch authors (Smolders et al. 2009) and a more recent Tunisian meta-analysis of 13 case-control studies including 3300 patients and 3194 controls (Tizaoui et al. 2015), both confirmed an association of multiple sclerosis with certain polymorphism of VDR gene.

Only 17 references were provided when key words VDR polymorphism and Parkinson were entered into PubMed database. The most recent population studies including more than 100 patients and age and sex matched controls originated from East Asia: China (Lv et al. 2013), Japan (Tanaka et al. 2017) and Korea (Kang et al. 2016). They did not provide a convincing evidence for association of VDR polymorphism and susceptibility to Parkinson's disease, though certain differences in studied gene alleles were found. The meta-analysis of so far available data is needed.

\section{Diabetes mellitus type 2}

Large meta-analyses were also performed on association of VDR polymorphisms with type 2 diabetes as for instance Zhu et al. (2014), Yu et al. (2016), but no clear evidence for association of with VDR polymorphisms were found.

\section{Conclusion}

We have attempted to summarize reasons of the impaired sensitivity or resistance to vitamin D. More attention was devoted to recent knowledge of the mechanisms of vitamin $\mathrm{D}$ action, both genomic and non-genomic, and the possible consequences resulting in its resistance. Briefly major pathologies are mentioned responsible for impaired vitamin D responsiveness. It is clear now that phenomenon of resistance or non-responsiveness to vitamin $\mathrm{D}$ is not confined only on genetic disorders in vitamin $\mathrm{D}$ receptor expression and biosynthesis, but it should be searched in the impairment of vitamin D signaling, taking into account various factors which there take place.

\section{Conflict of Interest}

There is no conflict of interest.

\section{Acknowledgement}

This work was supported by a project of the Ministry of Health of the Czech Republic - RVA (,Endokrinologický ústav - EÚ00023761“).

\section{References}

ADAMS JS, CHEN H, CHUN R, GACAD MA, ENCINAS C, REN S, NGUYEN L, WU S, HEWISON M, BARSONY J: Response element binding proteins and intracellular vitamin D binding proteins: novel regulators of vitamin D trafficking, action and metabolism. J Steroid Biochem Mol Biol 89-90: 461-465, 2004. 
ARDESIA M, FERLAZZO G, FRIES W: Vitamin D and inflammatory bowel disease. Biomed Res Int 2015: 470805, 2015.

BARSONY J, RENYI I, MCKOY W: Subcellular distribution of normal and mutant vitamin D receptors in living cells. Studies with a novel fluorescent ligand. J Biol Chem 272: 5774-5782, 1997.

BEKENSTEIN U, SOREQ H: Heterogeneous nuclear ribonucleoprotein A1 in health and neurodegenerative disease: from structural insights to post-transcriptional regulatory roles. Mol Cell Neurosci 56: 436-446, 2013.

BOUILLON R, VERSTUYF A, MATHIEU C, VAN CROMPHAUT S, MASUYAMA R, DEHAES P, CARMELIET G: Vitamin D resistance. Best Pract Res Clin Endocrinol Metab 20: 627-645, 2006.

BUITRAGO C, PARDO VG, BOLAND R: Role of VDR in 1 $\alpha, 25$-dihydroxyvitamin D3-dependent non-genomic activation of MAPKs, Src and Akt in skeletal muscle cells. J Steroid Biochem Mol Biol 136: 125-130, 2013.

CANTORNA MT, WADDELL A: The vitamin D receptor turns off chronically activated T cells. Ann N Y Acad Sci 1317: 70-75, 2014.

CHEN H, HU B, ALLEGRETTO EA, ADAMS JS: The vitamin D response element-binding protein. A novel dominant-negative regulator of vitamin D-directed transactivation. J Biol Chem 275: 35557-35564, 2000.

CHEN H, HEWISON M, HU B, ADAMS JS: Heterogeneous nuclear ribonucleoprotein (hnRNP) binding to hormone response elements: a cause of vitamin D resistance. Proc Natl Acad Sci U S A 100: 6109-6114, 2003.

CHRISTAKOS S, DHAWAN P, VERSTUYF A, VERLINDEN L, CARMELIET G: Vitamin D: metabolism, molecular mechanism of action, and pleiotropic effects. Physiol Rev 96: 365-408, 2016.

DE JONGH RT, VAN SCHOOR NM, LIPS P: Changes in vitamin D endocrinology during aging in adults. Mol Cell Endocrinol 453: 144-150, 2017.

DOROUDI M, SCHWARTZ Z, BOYAN BD: Membrane-mediated actions of 1,25-dihydroxy vitamin D3: a review of the roles of phospholipase $\mathrm{A} 2$ activating protein and $\mathrm{Ca}(2+) /$ calmodulin-dependent protein kinase II. $J$ Steroid Biochem Mol Biol 147: 81-84, 2015.

DUSSO AS, THADHANI R, SLATOPOLSKY E: Vitamin D receptor and analogs. Semin Nephrol 24: 10-16, 2004.

FISCHER J, WANG TT, KALDRE D, ROCHEL N, MORAS D, WHITE JH, GLEASON JL: Synthetically accessible non-secosteroidal hybrid molecules combining vitamin $\mathrm{D}$ receptor agonism and histone deacetylase inhibition. Chem Biol 19: 963-971, 2012.

GALESANU C, MOCANU V: Vitamin D deficiency and the clinical consequences. Rev Med Chir Soc Med Nat Iasi 119: 310-318, 2015.

GEZEN-AK D, DURSUN E, BILGIÇ B, HANAĞASI H, ERTAN T, GÜRVIT H, EMRE M, EKER E, ULUTIN T, UYSAL O, YILMAZER S: Vitamin D receptor gene haplotype is associated with late-onset Alzheimer's disease. Tohoku J Exp Med 228: 189-196, 2012.

GIARDINA C, MADIGAN JP, TIERNEY CA, BRENNER BM, ROSENBERG DW: Vitamin D resistance and colon cancer prevention. Carcinogenesis 33: 475-482, 2012.

GILARDI F, DESVERGNE B: RXRs: collegial partners. Subcell Biochem 70: 75-102, 2014.

GROBER U, REICHRATH J, HOLICK MF: Live longer with vitamin D? Nutrients 7: 1871-1880, 2015.

HAMPL R, VONDRA K: Peripheral sensitivity to steroids revisited. Physiol Res 66 (Suppl 3): S295-S303, 2017.

HAUSSLER MR, HAUSSLER CA, JURUTKA PW, THOMPSON PD, HSIEH JC, REMUS LS, SELZNICK SH, WHITFIELD GK: The vitamin D hormone and its nuclear receptor: molecular actions and disease states. J Endocrinol 154 (Suppl): S57-S73, 1997.

HAUSSLER MR, WHITFIELD GK, HAUSSLER CA, HSIEH JC, THOMPSON PD, SELZNICK SH, DOMINGUEZ CE, JURUTKA PW: The nuclear vitamin D receptor: biological and molecular regulatory properties revealed. J Bone Miner Res 13: 325-349, 1998.

HAUSSLER MR, WHITFIELD GK, KANEKO I, HAUSSLER CA, HSIEH D, HSIEH JC, JURUTKA PW: Molecular mechanisms of vitamin D action. Calcif Tissue Int 92: 77-98, 2013.

HAWA NS, COCKERILL FJ, VADHER S, HEWISON M, RUT AR, PIKE JW, O'RIORDAN JL, FARROW SM: Identification of a novel mutation in hereditary vitamin D resistant rickets causing exon skipping. Clin Endocrinol (Oxf) 45: 85-92, 1996.

HERIAN M, LUCK MR, GRZESIAK M: The influence of testosterone on the expression and function of vitamin D3 receptor (VDR) protein in the porcine ovarian follicle. Physiol Res 67: 515-519, 2018. 
HEWISON M, O'RIORDAN JL: Hormone-nuclear receptor interactions in health and disease. Vitamin D resistance. Baillieres Clin Endocrinol Metab 8: 305-315, 1994.

HEWISON M, RUT AR, KRISTJANSSON K, WALKER RE, DILLON MJ, HUGHES MR, O'RIORDAN JL: Tissue resistance to 1,25-dihydroxyvitamin D without a mutation of the vitamin D receptor gene. Clin Endocrinol (Oxf) 39: 663-670, 1993.

HII CS, FERRANTE A: The non-genomic actions of vitamin D. Nutrients 8: 135-149, 2016.

HUGHES MR, MALLOY PJ, KIEBACK DG, KESTERSON RA, PIKE JW, FELDMAN D, O'MALLEY BW: Point mutations in the human vitamin D receptor gene associated with hypocalcemic rickets. Science 242: 1702-1705, 1988.

HUGHES MR, MALLOY PJ, O'MALLEY BW, PIKE JW, FELDMAN D: Genetic defects of the 1,25-dihydroxyvitamin D3 receptor. J Recept Res 110: 699-716, 1991.

HUHTAKANGAS JA, OLIVERA CJ, BISHOP JE, ZANELLO LP, NORMAN AW: The vitamin D receptor is present in caveolae-enriched plasma membranes and binds 1 alpha,25(OH)2-vitamin D3 in vivo and in vitro. Mol Endocrinol 18: 2660-2671, 2004.

JOLLIFFE DA, WALTON RT, GRIFFITHS CJ, MARTINEAU AR: Single nucleotide polymorphisms in the vitamin D pathway associating with circulating concentrations of vitamin D metabolites and non-skeletal health outcomes: review of genetic association studies. J Steroid Biochem Mol Biol 164: 18-29, 2016.

KANG SY, PARK S, OH E, PARK J, YOUN J, KIM JS, KIM JU, JANG W: Vitamin D receptor polymorphisms and Parkinson's disease in a Korean population: revisited. Neurosci Lett 628: 230-235, 2016.

KATO S: Genetic mutation in the human 25-hydroxyvitamin D3 1alpha-hydroxylase gene causes vitamin D-dependent rickets type I. Mol Cell Endocrinol 156: 7-12, 1999.

KIM CJ, KAPLAN LE, PERWAD F, HUANG N, SHARMA A, CHOI Y, MILLER WL, PORTALE AA: Vitamin D 1alpha-hydroxylase gene mutations in patients with 1alpha-hydroxylase deficiency. $J$ Clin Endocrinol Metab 92: 3177-3182, 2007.

KOREN R: Vitamin D receptor defects: the story of hereditary resistance to vitamin D. Pediatr Endocrinol Rev 3 (Suppl 3): 470-475, 2006.

MILLER WL: Genetic disorders of vitamin D biosynthesis and degradation. J Steroid Biochem Mol Biol 165: 101-108, 2017.

ŁACZMAŃSKI Ł, JAKUBIK M, BEDNAREK-TUPIKOWSKA G, RYMASZEWSKA J, SŁOKA N, LWOW F: Vitamin D receptor gene polymorphisms in Alzheimer's disease patients. Exp Gerontol 69: 142-147, 2015.

LANG PO, ASPINALL R: Vitamin D status and the host resistance to infections: what it is currently (not) understood. Clin Ther 39: 930-945, 2017.

LEE SM, MEYER MB, BENKUSKY NA, O'BRIEN CA, PIKE JW: Mechanisms of enhancer-mediated hormonal control of vitamin D receptor gene expression in target cells. J Biol Chem 290: 30573-30586, 2015.

LIBERMAN UA, SAMUEL R, HALABE A, KAULI R, EDELSTEIN S, WEISMAN Y, PAPAPOULOS SE, CLEMENS TL, FRAHER LJ, O'RIORDAN JL: End-organ resistance to 1,25-dihydroxycholecalciferol. Lancet 1: 504-506, 1980.

LIBERMAN UA, EIL C, HOLST P, ROSEN JF, MARX SJ: Hereditary resistance to 1,25-dihydroxyvitamin D: defective function of receptors for 1,25-dihydroxyvitamin D in cells cultured from bone. J Clin Endocrinol Metab 57: 9589-9662, 1983.

LONG MD, SUCHESTON-CAMPBELL LE, CAMPBELL MJ: Vitamin D receptor and RXR in the post-genomic era. J Cell Physiol 230: 758-766, 2015.

LV Z, TANG B, SUN Q, YAN X, GUO J: Association study between vitamin D receptor gene polymorphisms and patients with Parkinson disease in Chinese Han population. Int J Neurosci 123: 60-64, 2013.

MÁČOVÁ L, BIČÍKOVÁ M, OSTATNÍKOVÁ D, HILL M, STÁRKA L: Vitamin D, neurosteroids and autism. Physiol Res 66 (Suppl 3): S333-S340, 2017.

MALLOY PJ, FELDMAN D: The role of vitamin D receptor mutations in the development of alopecia. Mol Cell Endocrinol 347: 90-96, 2011.

MANOLAGAS SC, PROVVEDINI DM, TSOUKAS CD: Interactions of 1,25-dihydroxyvitamin D3 and the immune system. Mol Cell Endocrinol 43: 113-122, 1985. 
MILLER WL: Genetic disorders of Vitamin D biosynthesis and degradation. J Steroid Biochem Mol Biol 165: 101-108, 2017.

NICOLAIDOU P, PAPADOPOULOU A, MATSINOS YG, GEORGOULI H, FRETZAYAS A, PAPADIMITRIOU A, PRIFTIS K, DOUROS K, CHROUSOS GP: Vitamin D receptor polymorphisms in hypocalcemic vitamin D-resistant rickets carriers. Horm Res 67: 179-183, 2007.

ORDÓÑEZ-MORÁN P, MUÑOZ A: Nuclear receptors: genomic and non-genomic effects converge. Cell Cycle 8: 1675-1680, 2009.

PENESOVÁ A, DEAN Z, KOLLÁR B, HAVRANOVÁ A, IMRICH R, VLČEK M, RÁDIKOVÁ Ž: Nutritional intervention as an essential part of multiple sclerosis treatment? Physiol Res 67: 521-533, 2018.

PIKE JW, MEYER MB: The vitamin D receptor: new paradigms for the regulation of gene expression by 1,25-dihydroxyvitamin D3. Endocrinol Metab Clin North Am 39: 255-269, 2010.

PIKE JW, MEYER MB, BENKUSKY NA, LEE SM, ST JOHN H, CARLSON A, ONAL M, SHAMSUZZAMAN S: Genomic determinants of vitamin D-regulated gene expression. Vitam Horm 100: 21-44, 2016.

PORTALE AA, MILLER WL: Human 25-hydroxyvitamin D-1alpha-hydroxylase: cloning, mutations, and gene expression. Pediatr Nephrol 14: 620-625, 2000.

SACCONE D, ASANI F, BORNMAN L: Regulation of the vitamin D receptor gene by environment, genetics and epigenetics. Gene 561: 171-180, 2015.

SANDGREN ME, DELUCA HF: An immunoradiometric assay for 1,25-dihydroxyvitamin D3 receptor. Anal Biochem 183: 57-63, 1989.

SMOLDERS J, PEELEN E, THEWISSEN M, MENHEERE P, TERVAERT JW, HUPPERTS R, DAMOISEAUX J: The relevance of vitamin D receptor gene polymorphisms for vitamin D research in multiple sclerosis. Autoimmun Rev 8: 621-626, 2009.

SONE T, SCOTT RA, HUGHES MR, MALLOY PJ, FELDMAN D, O'MALLEY BW, PIKE JW: Mutant vitamin D receptors which confer hereditary resistance to 1,25-dihydroxyvitamin D3 in humans are transcriptionally inactive in vitro. $J$ Biol Chem 264: 20230-20234, 1989.

SUTHERLAND MK, SOMERVILLE MJ, YOONG LK, BERGERON C, HAUSSLER MR, MCLACHLAN DR: Reduction of vitamin D hormone receptor mRNA levels in Alzheimer as compared to Huntington hippocampus: correlation with calbindin-28k mRNA levels. Brain Res Mol Brain Res 13: 239-250, 1992.

TANAKA K, MIYAKE Y, FUKUSHIMA W, KIYOHARA C, SASAKI S, TSUBOI Y, OEDA T, SHIMADA H, KAWAMURA N, SAKAE N, FUKUYAMA H, HIROTA Y, NAGAI M, NAKAMURA Y, FUKUOKA K: Vitamin D receptor gene polymorphisms, smoking, and risk of sporadic Parkinson's disease in Japan. Neurosci Lett 643: 97-102, 2017.

TIZAOUI K, KAABACHI W, HAMZAOUI A, HAMZAOUI K: Contribution of VDR polymorphisms to type 1 diabetes susceptibility: systematic review of case-control studies and meta-analysis. $J$ Steroid Biochem Mol Biol 143: 240-249, 2014.

TIZAOUI K, KAABACHI W, HAMZAOUI A, HAMZAOUI K: Association between vitamin D receptor polymorphisms and multiple sclerosis: systematic review and meta-analysis of case-control studies. Cell Mol Immunol 12: 243-252, 2015.

TROCHOUTSOU A, KLOUKINA V, SAMITAS K, XANTHOU G: Vitamin-D in the immune system: genomic and non-genomic actions. Mini Rev Med Chem 215: 953-963, 2015.

TUORESMÄKI P, VÄISÄNEN S, NEME A, HEIKKINEN S, CARLBERG C: Patterns of genome-wide VDR locations. PLoS One 9: e96105, 2014.

VINCKEVICIUS A, CHAKRAVARTI D: Chromatin immunoprecipitation: advancing analysis of nuclear hormone signaling. J Mol Endocrinol 49: R113-R123, 2012.

WANG Y, ZHU J, DELUCA HF: Where is the vitamin D receptor? Arch Biochem Biophys 523: 123-133, 2012.

WHITE JH: Vitamin D deficiency and the pathogenesis of Crohn's disease. J Steroid Biochem Mol Biol 175: 23-28, 2018. 
WHITFIELD GK, SELZNICK SH, HAUSSLER CA, HSIEH JC, GALLIGAN MA, JURUTKA PW, THOMPSON PD, LEE SM, ZERWEKH JE, HAUSSLER MR: Vitamin D receptors from patients with resistance to 1,25-dihydroxyvitamin D3: point mutations confer reduced transactivation in response to ligand and impaired interaction with the retinoid X receptor heterodimeric partner. Mol Endocrinol 10: 1617-1631, 1996.

WIESE RJ, GOTO H, PRAHL JM, MARX SJ, THOMAS M, AL-AQEEL A, DELUCA HF: Vitamin D dependency rickets type II: truncated vitamin D receptor in three kindreds. Mol Cell Endocrinol 90: 197-201, 1993.

YANG L, WU L, FAN Y, MA J: Associations among four polymorphisms (BsmI, FokI, TaqI and ApaI) of vitamin D receptor gene and end-stage renal disease: a meta-analysis. Arch Med Res 46: 1-7, 2015.

YU F, CUI LL, LI X, WANG CJ, BA Y, WANG L, LI J, LI C, DAI LP, LI W: The genetic polymorphisms in vitamin D receptor and the risk of type 2 diabetes mellitus: an updated meta-analysis. Asia Pac J Clin Nutr 25: 614-624, 2016.

ZANATTA L, ZAMONER A, ZANATTA AP, BOURAÏMA-LELONG H, DELALANDE C, BOIS C, CARREAU S, SILVA FR: Nongenomic and genomic effects of $1 \alpha, 25(\mathrm{OH}) 2$ vitamin D3 in rat testis. Life Sci 89: 515-523, 2011.

ZHU B, ZHAO HL, OU C, HUANG LS, LI PZ, LAO M: Association of vitamin D receptor BsmI gene polymorphism with the risk of type 2 diabetes mellitus. J Recept Signal Transduct Res 34: 458-462, 2014. 